\title{
Research on Indigenous Fish Species in Lao PDR: A Review of Investigations into Aquaculture Development, Fisheries Management and Conservation
}

\section{Morioka $S^{*}$}

Senior Researcher, Fisheries Division, Japan International Research Center for Agricultural Sciences, Japan

*Corresponding author: Shinsuke Morioka, Senior Researcher, Fisheries Division,

Review Article

Volume 2 Issue 1

Received Date: December 22, 2017

Published Date: January 05, 2018 Japan International Research Center for Agricultural Sciences, 1-1 Owashi, Tsukuba 305-0086, Japan, Tel: +80-29-8386357; E-mail: moriokas@affrc.go.jp

\section{Abstract}

A rich diversity of indigenous fish is present on the Indochinese Peninsula, particularly in the Mekong Basin. Since the $20^{\text {th }}$ century, a number of alien fishes have been introduced into the region primarily for the development of aquaculture, and there is increasing concern regarding the potential for loss of regional biodiversity and for a decline in the stock of indigenous fishes. Consequently, efficient utilization of indigenous fishes for aquaculture is desirable. Therefore, biological surveys are required to support their conservation. This article reviews research carried out by the author in Lao PDR into the early morphological development and biology of several indigenous fish species in relation to aquaculture development, fisheries management and species conservation.

Keywords: Mekong Basin; Indigenous fishes; Aquaculture; Biology

\section{Introduction}

Lao PDR is a country with a rich resource of indigenous fish species, particularly in the basins of the Mekong River and its tributaries. Estimates of the numbers of indigenous fish species in this region range from 700 to more than 1,200 many of which provide important protein sources for human consumption [1,2]. However, since the $20^{\text {th }}$ century, the increasing population of Lao PDR and over-fishing of natural fish resources [3] has led to the introduction of substantial numbers of alien fishes for aquaculture, particularly tilapia Oreochromisniloticus, common carp Cyprinus carpio and Chinese carps (e.g., the grass carp Ctenopharyngodon idella and silver carp Hypophthalmichthys molitrix) $[4,5]$. In consequence, more than 20 invasive alien species are now considered to have established natural breeding populations in the Mekong region. The presence of these alien fishes is an important concerned issue because of a potential for decline in the region's native and endemic fish diversity and their stock levels. To date, studies aimed at conservation and efficient use of indigenous fishes in aquaculture and fisheries have included fundamental research on systematics $[1,6]$ an evaluation of genetic introgression by introduced Clarias 


\section{International Journal of Oceanography \& Aquaculture}

gariepinus [7] a report on the aquaculture potential of indigenous fishes[4] and investigations of fisheries resource management $[8,9]$. However, there is limited information on the biology and morphological development of larval and juvenile fishes in relation to seed production, which is essential for aquaculture and fisheries management and for understanding the conservation biology of non-aquaculture species. Therefore, recent research activities by the author are introduced and reviewed of this article here. These findings also help to elucidate the evolutionary ecology of each fish species.

\section{Overview of Research Activities on Aquaculture and Fisheries in Lao PDR \\ Studies of Morphological Development of Larvae and Juveniles for Improving Seed Production}

As mentioned above, settlement of invasive alien fishes has increased concern regarding the potential loss of regional biodiversity [10] suggesting a need for greater emphasis on proliferation of indigenous fish species and on stock conservation in the Indochina region $[4,5]$. Accordingly, seed production and aquaculture based on indigenous fishes require further promotion in the region. Successful production of good quality seed requires data on morphological development of larval and juvenile stages, and this information is contributory to aquaculture and also to considerations of the diversity and evolutionary ecology of each species.

The climbing perch Anabas testudineus (Anabantidae) [11] an indigenous fish in the suborder Anabantoidei, is an important target of aquaculture. The basic features of morphological development of this species have been described (Figures 1 \& 2) [11]. Subsequent investigations of three anabantoid species, i.e., the snake skin gourami Trichogaster pectoralis [12] the three spot gourami $T$. trichopterus [13] and the giant gourami Osphronemusgoramy [14], compared morphological and behavioral development and the early biology of larval and juvenile stages (Figure 3). Besides helping to improve seed production of these species, these findings are relevant to the ecology of related taxa.



\section{International Journal of Oceanography \& Aquaculture}



Figure 3: Schematic comparison of four anabantoid species, Anabas testudineus (Anabantidae), Trichogastertrichopterus, T. pectoralis and Osphronemus goramy (Osphronemidae), in terms of four selected characters: yolksac period, timing of the shift from larval to juvenile stages, membrane development of labyrinth organ, and timing of extension of first pelvic fin soft ray (for the latter three species). Figure modified from Morioka et al. (2013)[14].

Similar studies have been made on other fishes in the family Cyprinidae, including the goldfin tinfoil barb Hypsibarbus malcolmi [15] and the small-scale mud carp Cirrhinus microlepis [16] and in the order Siluriformes, including the striped cat fish Pangasianodon hypophthalmus (Pangasiidae)[17] Hemibagrus filamentus (Bagridae) [18] and the bighead cat fish Clarias macrocephalus (Clariidae)[19] to improve seed production and to facilitate morphological comparisons among taxonomic groups.

\section{Fish biology in relation to conservation and stock management}

Conservation of fish diversity and stock management require basic information on the life history of selected species, including growth rates, time to sexual maturity and generation times. As the first example, the bumblebee go by Brachygobius mekogensis [20] is a small gobiid fish (ca. 14-mm maximum standard length) in Lao PDR. Age estimates using daily otolith increments and gonad analyses of this species demonstrated its short life-span and the early maturation of this species (Figures. 4, 5) leading to occurrence of multiple generation alternations per year. These findings will help to develop conservation measures for this species. Another studied example is the striped snakehead Channa striata, a carnivorous channid fish [21] which is distributed widely over western and southeastern Asia. This species is an important target of commercial fisheries and is constantly under high fishing pressure. Age and gonad analyses of this species provided information on growth patterns and the reproductive period for a local population of the species in Lao PDR.

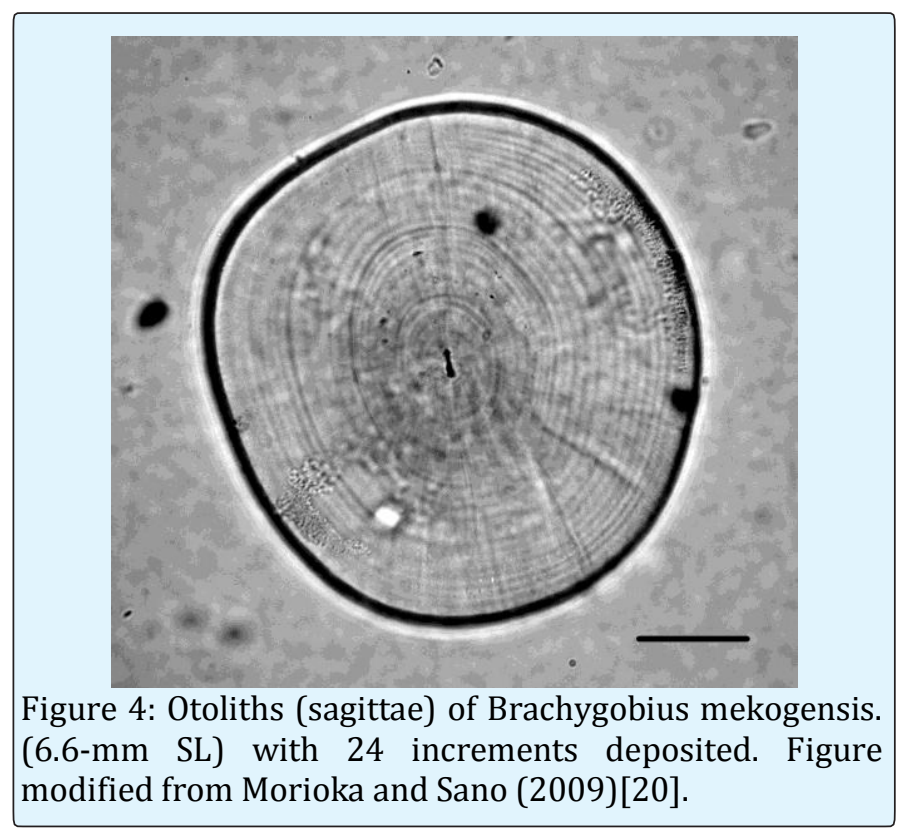




\section{International Journal of Oceanography \& Aquaculture}

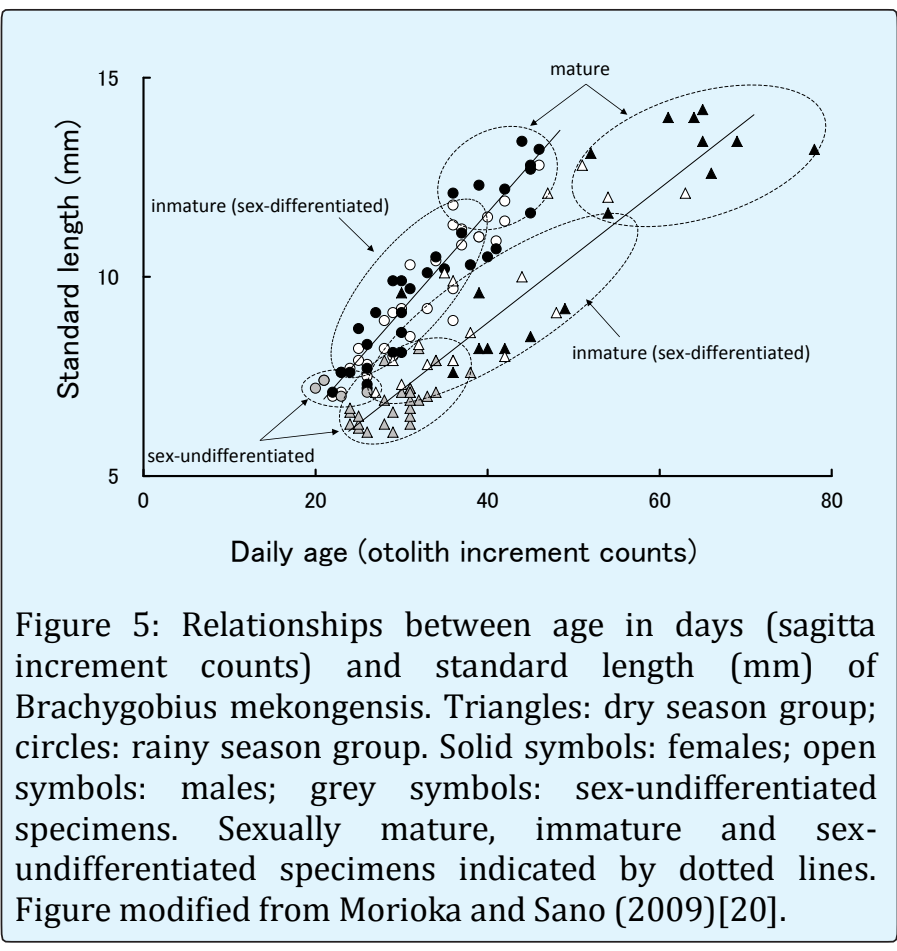

Similar studies in relation to conservation and stock management have been made for other indigenous species, e.g., the grass perch Parambassis siamensis (Ambassidae) [22] and Rasbora rubrodorsalis (Cyprinidae) [23].

\section{Conclusion}

The above sections reviewed several investigations of regional indigenous fishes with respect to aspects of aquaculture, fisheries management and conservation. Beside these studies on biological aspects, a variety of investigations have been made on environmental impacts for species conservation in the region. However, alien species are still present and are considered increasing, as yet, and generating further risk to indigenous biodiversity. Therefore, investigations aimed at substantial reduction and ideally extermination, of invasive alien species are now urgently required, as well as surveys of indigenous species, as reviewed in this article.

\section{References}

1. Kottelat M (2001) Fishes of Laos. Wildlife Heritage Trust, Colombo, pp: 198.

2. Sverdrup Jensen S (2002) Fisheries in the lower Mekong Basin: status and perspectives. MRC Technical Paper 6, Phnom Penh, pp: 103.
3. Food and Agriculture Organization (FAO) (2006) Fishery country profile Lao P.D.R., Rome, pp: 18.

4. Phillips MJ (2002) Freshwater aquaculture in the Lower Mekong Basin. MRC Technical Paper No. 7, Mekong River Commission, Phnom Penh pp: 62.

5. Welcomme RL, Vidthayanon C (2003) The impact of introductions and stocking of exotic species in the Mekong basin and policies for their control. MRC Technical Paper No. 9. Mekong River Commission, Phnom Penh pp: 35.

6. Rainboth WJ (1996) Fishes of the Cambodian Mekong. FAO Species Identification Field Guide for Fishery Purposes. FAO, Rome, pp: 265.

7. Na-Nakorn U, Kamonrat $\mathrm{W}$, Ngamsiri $\mathrm{T}$ (2004) Genetic diversity of walking catfish, Clarias macrocephalus, in Thailand and evidence of genetic introgression from introduced farmed C. gariepinus. Aquaculture 240: 145-163.

8. Lim P, Lek S, Touch ST, Mao S, Chhouk B (1999) Diversity and spatial distribution of freshwater fish in Great Lake and Tonle Sap River (Cambodia, Southeast Asia). Aquatic Living Resources 12(6): 379-386.

9. Jutagate T, Krudpan C, Ngamsnae P, Lamkom T, Payooha K (2005) Changes in the fish catches during a trial opening of sluice gates on a run-of-the river reservoir in Thailand. Fisheries Management and Ecology 12(1): 57-62.

10. Nguyen TTT, De Silva SS (2006) Freshwater finfish biodiversity and conservation: an Asian perspective. Biodiversity and Conservation 15(11): 3543-3568.

11. Morioka S, Ito S, Kitamura S, Vongvichith B (2009) Growth and morphological development of laboratory-reared larval and juvenile climbing perch Anabas testudineus. Ichthyological Research 56: 162171.

12. Morioka S, Ito S, Kitamura S (2010) Growth and morphological development of laboratory-reared larval and juvenile snakeskin gourami Trichogaster pectoralis. Ichthyological Research 57: 24-31.

13. Morioka S, Chanthasone $\mathrm{P}$, Phommachan $\mathrm{P}$, Vongvichith B (2011) Growth and morphological development of laboratory-reared larval and juvenile three-spot gourami Trichogastertric hopterus. Ichthyological Research 59: 53-62. 


\section{International Journal of Oceanography \& Aquaculture}

14. Morioka S, Vongvichith B, Phommachan P, Chantasone P (2013) Growth and morphological development of laboratory-reared larval and juvenile giant gourami Osphronemusgoramy Perciformes: Osphronemidae). Ichthyological Research 60: 209217.

15. Ogata Y, Morioka S, Sano K, Vongvichith B, Eda H, et al. (2010) Growth and morphological development of laboratory-reared larvae and juveniles of the Laotian indigenouscyprinid Hypsibarbus malcolmi. Ichthyological Research 57: 389-397.

16. Morioka S, Cacot P, Moteki M, Tthipvantong V, Philavong S, et al. (2011c) Ontogenetic development during changeover from an endogenous to exogenous nutritional source in Laotian cyprinid Cirrhinus microlepis larvae. Fisheries Science 78(2): 221-227.

17. Morioka S, Sano K, Phommachan P, Vongvichith B (2010b) Growth and morphological development of laboratory-reared larval and juvenile Pangasianodon hypophthalmus. Ichthyol Res 57: 139-147.

18. Morioka S, Vongvichith B (2011b) Growth and morphological development of laboratory-reared larval and juvenile Hemibagrus filamentus (Siluriformes: Bagridae). Ichthyological Research 58: 245-254.
19. Morioka S, Vongvichith $\mathrm{B}$, Phommachan $\mathrm{P}$, Chantasone P (2013) Growth and morphological development of laboratory-rearedlarval and juvenile bighead catfish Clarias microcephalus (Siluriformes: Clariidae). Ichthyological Research 60(1): 16-25.

20. Morioka S, Sano K (2009) Growth and maturation of the bumble-bee goby Brachygobius mekongensis (Perciformes: Gobiidae) occurring in the Mekong basin, in Vientiane Province, Central Laos. Ichthyological Exploration of Freshwaters 20(3): 267275.

21. Morioka S, Vongvichith $B$, Chanthasone $P$, Phommachane P, Suzuki N (2016) Reproductive season, age estimation and growth in a striped snakehead Channastriata population in Nasaythong District, Vientiane Province, Central Laos. Aquaculture Science 64(2): 183-191.

22. Okutsu T, Morioka S, Shinji J, Chanthasone P (2011) Growth and reproduction of the glassperch Parambassissiamensis (Teleostei: Ambassidae) in Central Laos. Ichthyological Exploration of Freshwaters 22(2): 97-106.

23. Morioka S, Koizumi N, Vongvichith B (2014) Seasonal growth and reproduction of Rasbora rubrodorsalis, a small-sized cyprinid fish from central Laos (Teleostei: Cyprinidae). Ichthyological Exploration of Freshwaters 25(3): 277-287. 